\title{
Liberal Market Economies, Business, and Political Finance: Britain under New Labour
}

\author{
Iain McMenamin, \\ Centre for International Studies and School of Law and Government, \\ Dublin City University
}

Final Version for West European Politics, 11 March 2011

8,510 words (including title page, appendix, figures, tables and references)

The extent and nature of business financing of parties is an important feature of political finance. Britain's transparent and permissive regulatory system provides an excellent opportunity to study business financing of parties. Business donations have been very important to the Conservative party over the last decade, and of only marginal importance to Labour. Unlike other Conservative contributors, business donors are more likely to contribute when the party is popular. In contrast to the previous period of Conservative government, the biggest British businesses tended to abstain from political finance under New Labour. However, their bias towards the Conservatives is affected by the party's popularity and the closeness of an election. Britain shares the political importance of business financing of parties and its mixture of ideological and pragmatic motivations with other liberal market economies. However, in Britain the bias towards the right is much stronger and the role of big business more marginal.

Key words: Britain, political finance, business-government relations, interest groups

Acknowledgments: Conor McKeating played an invaluable role in an earlier phase of this project. Tim Bale generously commented on a previous draft. I am grateful to Danielle Greene, Peter McCrossan, Cliona McParland and Juan Muñoz-Portillo for research assistance and the Faculty of Humanities and Social Sciences and Business School, Dublin City University for financial support. 
Britain now generates more and better information about political finance than almost any other country. Nonetheless, the data created by the Political Parties Elections and Referendums Act has not inspired a new wave of analysis. Strangely, previous quantitative studies relate to the earlier period when figures were much more difficult to obtain (Bond 2007; Fisher 1992; Fisher 2000; Mitchell and Bretting 1993). Writing on the subject tends to emphasise aggregate figures, critique of the legal and administrative system, and the recapitulation of media controversies. In doing so, the literature assumes a party-centred approach. This style of research has shown its worth, but, clearly, political fundraising involves donors as well as donees. This article exploits the potential of UK official data to shed light on the motivations of business donors (Scarrow 2006). Business money is the most controversial source of political finance. Indeed, business financing of political parties always generates a tensions between votes (the currency of democracy) and pounds (the currency of capitalism) (Lindblom 1977: 189-200; Vogel 1996).

The political context since official disclosure began in 2001 provides several opportunities. This was the era of New Labour. Tony Blair went as far as asserting that Labour was the "natural party of business" (Coen and Grant 2006: 17). Was business sufficiently convinced to begin offering financial support to the Labour party? Labour's triumph was the Conservatives' rout and the pre-Cameron period represents the darkest era in the history of the post-war Conservative party (Bale 2009: 224). By contrast, in recent years, Labour, under both Blair and Brown, had become a tired party that seemed to have spent too long in government. In other words, the popularity of the parties, and their prospects of controlling government, varied hugely in this period. This enables us to separate business sympathy towards 
the Conservative party from business recognition that the Conservatives have tended to win British elections. As well as these political conditions, the legislation itself is likely to have affected behaviour (Scarrow 2007: 202). Disclosure may well have reduced business donations, as firms receive unwelcome publicity and complaints from shareholders. Indeed, disclosure and politics probably interact. When a reforming Australian Labor Party (ALP) introduced disclosure in the 1980s, it began writing to conservative donor businesses asking that they also contribute to the ALP (Gordon and Ceresa: 1995). New Labour was perhaps more subtle, but businesses may have decided that donations to Labour were a cheap insurance against political risks from one of the world's most powerful executives. This article links such questions in a comparative framework. I look at the contribution rate and whether donations have been pragmatically or ideologically motivated. Previous research on Australia, Canada, Germany and the United States suggests that contribution rates are much higher in liberal market economies. Also, if such economies are combined with an ideologically-structured party system, business financing of parties should display both ideological and pragmatic motivations. The article is organised straightforwardly. In the next section, I introduce the key concepts of pragmatism and ideology in political finance. I then present hypotheses to explain cross-national variation. Then after a discussion of the regulatory, economic and political context of the British case, I move on to the empirical core of the paper, which analyses in turn three new databases on business behaviour in British political finance.

\section{Motivations for Business Financing of Political Parties}

Business contributions to political parties can be conceived in terms of two general motivations: ideological and pragmatic. Ideological contributions are not likely to 
survive a cost-benefit analysis because, whatever the possible benefits, it is rational to free ride on the contributions of other businesses to the long-term class-wide interest (Olson 1971). Ideological contributions are made to the political actors most likely to promote capitalism in general, regardless of whether any specific benefits will accrue to the contributing firm. The distribution of ideologically motivated donations should be relatively stable over time. Party ideologies change slowly. Even if parties tack to the left or the right for tactical reasons, it is rare for the left-right ranking of parties to change. By contrast, pragmatic contributions are essentially business decisions, taken with the firm's usual profit-seeking motive. The distribution of pragmatic donations should follow short-term changes in the power and popularity of parties. These two motivations may interact in a single decision about the distribution of political contributions. For example, take a firm that has an ideological preference for the right. Under a left-wing government it may be prepared to contribute to the left, while also continuing to express its ideological preference by funding the right-wing opposition. Thus, a firm's distribution of cash to parties is a strategic decision taking into account political power and the firm's ideological position, if it has one.

Social factors also play an important part in business financing of political parties (Bond 2004). However, this can be seen as a mechanism of ideologically or pragmatically-motivated giving. In many countries, pragmatic donations to parties occur in the context of low corruption. In this situation, discrete exchanges such as the purchase of policy or even the purchase of access to decision-makers, incurs too high a reputational cost on politicians and businesses. Instead, donations form part of a reciprocal exchange. They help to develop and maintain a relationship with politicians, which may, in due course, produce a small but real increase in the 
probability of successful lobbying (Clawson, Neustadtl and Weller 1998; Gordon 2005; McMenamin 2012). Networks are also important in understanding ideological donations, but in this case the network precedes the donation. Many people are socialised into an ideological position and even socialised into a close relationship with a particular party. Indeed, the relationship between "public schools", high finance in the City of London and the Conservative Party is a classic example of this process.

Businesses and businesspeople are likely to be differently-motivated in making financial contributions to political parties (McMenamin 2009: 212-213). Individuals are more likely to make ideological contributions. In contrast to firms, they do not have to justify their decision to shareholders. Individuals can use cash generated by business activities to further their political values as opposed to their business interests. Of course, rich individuals are also interested in getting richer and may also be motivated pragmatically. Individuals are particularly likely to be influenced by social position. It is they who actually went to certain schools, frequent certain clubs and sit on certain boards.

The incentives facing firms push them towards pragmatic motivations. Most firms are explicitly dedicated to making a profit. Therefore, a well-run firm should not be tempted to make ideological gestures, even if such gestures are consistent with the social positions of the firm's management and owners. Publicity imposes a reputational cost on a firm and a politician (Grant 1993 144). Therefore, firms may be tempted to route donations through individuals associated with the firm. In aggregate, firms and individuals should behave differently, but, in many instances, their motivations may overlap (Bond 2007: 59-60). 
Truly massive businesses find themselves in a different political situation to other firms (Coen 1997, 99; Grant 1993: 87-88). Their financial resources are so great as to be seemingly limitless in the penny-pinching world of political finance. Cash donations, even ones that seem huge to ordinary individuals do not constitute a large, or perhaps even a noticeable, cost to big businesses. Such businesses are much more visible than other businesses because of their size and, in many cases, also because of the prominence of their brand in everyday life. This visibility is the real cost of financing political parties for big businesses. It can affect a business in a number of ways. Controversy can damage the firm's reputation amongst the public. Donations can be costly in this way regardless of the real or perceived motivations behind them. In public companies, political donations can lead to unwelcome controversy within the firm's own governance structures. Donations will probably be more visible to politicians than to the general public and the firm's shareholders. Ideological donations may attract the enmity of one side of politics, while perceived pragmatism may attract requests for money, and perhaps even potentially damaging offers of benefits, from all political parties.

Large businesses, by virtue of their importance to the economy, possess massive structural power. In contrast to smaller businesses, they do not necessarily need to buy the attention of politicians to their particular needs. However, financial contributions may serve to increase their influence yet further. Visibility imposes a potential cost on businesses, but that visibility is much more costly to politicians. In a democracy, politicians need to emphasise that the currency of votes trumps that of money. Thus, visibility places a very significant constraint on benefits that 
politicians may be willing to award to donor businesses. Nonetheless, the profits that can be gained from even subtle changes in public policy are so massive that there are always potential benefits to firms from engagement with the political system.

In the empirical sections of this article, I assess the evidence for ideologically and pragmatically-motivated donations amongst businesses in general, very large businesses and prominent individuals associated with large businesses.

\section{Explaining cross-national variation}

In liberal market economies, the highly competitive, short-term focus of firms should generate substantial demand for private goods that could help firms develop an advantage over their rivals. Pragmatism should be an important motivation for business financing of parties and since pragmatism is embedded in the basic profitseeking mission of the firm the contribution rate should be high. The preference for less state intervention, and the awareness of the state's power to disrupt the business environment, is likely to engender a widespread awareness of the importance of public policy goods to the overall business sector. This should result in a relatively important ideological motivation in business contributions to parties. However, this political effect should interact with the party system. In a polarised political system, the political risk should be greater. If there is a little difference between parties' economic policies and reputations, the ideological motivation is likely to be marginal. Australia and the United States are liberal economies. There is pragmatic giving to the major parties of the left and right along with an ideological bias towards the right (McMenamin 2008; Stratmann 2005). Canada's traditional governing parties enjoyed widespread pragmatic contributions until corporate donations were banned in 2004 . 
The two centrist, brokerage parties were treated remarkably equally by businesses (McMenamin 2012).

In a co-ordinated market economy, the most important policies for firms tend to be the public goods defined, championed, and, to a substantial extent, actually delivered by their business associations. In this context, the pragmatic motivation for contributions to political parties is likely to be very weak. The combination of consensual political institutions and constrained parties means there is a very low risk of major policy change from election to election (Iversen 2005: 122-182; Wood 2001). So, there is also likely to be low interest in ideological financing of political parties. Since both motivations are undermined by the political economy, the contribution rate should be very low. Germany, the archetypical co-ordinated market economy, exemplifies this pattern of business financing of parties (McMenamin 2012).

\section{The British case}

The regulation of British political finance has a long history. The first law on political finance dates back to 1883 when the Corrupt and Illegal Practices (Prevention) Act introduced a cap on spending at constituency level (Fisher 2009: 305). Although an intervention in private spending, this law expressed a reluctance to acknowledge the importance of parties, which was to endure through the twentieth century. The Political Parties, Elections and Referendums Act (PPERA) heralded a fundamental change in the theory and practice of British political finance regulation. It instigated an impressive level of transparency, a ban on foreign donations and spending limits 
for the parties. However, it did not introduce limits on the size or source of domestic donations; nor did it introduce substantial state funding.

Britain exhibits all the distinguishing characteristics of a liberal market economy (Hall and Soskice 2001: 19-21, 59; Wood 2001). It has a large stock market, which provides the principal means of corporate finance. Its labour market is flexible and it has a generalist education system. Business associations are weak. The prime minister and cabinet have operated under few constraints, or they did until the coalition formed after the 2010 general election. Firms are isolated from other businesses in their sector and under pressure to produce short-term profits. In this business environment, many should seek to use the political system to gain an advantage over their competitors. Moreover, the power of the executive creates a potential for costly policy swings. In this context, the ideology of government matters to business and the usual business preference for market rather than state is especially appealing. Britain's party system has a clear left-right structure, but the advent of New Labour reduced polarisation. Therefore, Britain should have relatively high contribution rate and substantial evidence of both pragmatic and ideologicallymotivated contributions. In the next section, I begin to test these predictions.

\section{Business donations}

This section examines donations and loans to the Labour and Conservative parties from companies from the $1^{\text {st }}$ of January 2001 until the end of May 2010. An inspection of the registers reveals that almost all business donations are from companies. Donations to officeholders are trivial in comparison to those received by the parties themselves. Indeed, there are very few donations to officeholders once 
free car parking spaces at airports and fact-finding trips to the Middle East are excluded. Loans are an important part of contemporary British party finance. I analyse them in the appendix and explain why they do not confound conclusions drawn from donations.

The data analysed in this section are available at http://www.dcu.ie/ mcmenami. As Figure 1 shows, the Conservatives received one quarter of their income from companies, but Labour well under five per cent. The Conservative party, because it was in opposition, received considerable public funding (Ewing 2005: 184-185). If the Conservative party had not had either public funding or substantial company funding, it would have had a similar income to Labour. If it had had neither, it would have had to do with a much smaller income than the Labour. Therefore, although it cannot be said that companies are the paymasters of the Conservative party, there seems to be some potential for them to influence the Conservatives. By contrast, business donations are barely noticeable to the Labour party.

[Figure 1 about here]

In the period since 2001, as Figure 2 illustrates, Conservative income from private donations has risen fairly gradually, excepting predictable spikes in advance of elections (Fisher 2000: 198). During this time, the popularity of the party has also increased, raising the possibility of a relationship between the two. However, a regression analysis controlling for the number of days to the next election, suggests no significant relationship between Conservative donations and the average quarterly poll value from ICM (Please see Table 1). The response of donors to the steep increase in popularity achieved by David Cameron was, at most, cautious and 
delayed. Figure 3, showing company donations to the Conservatives also suggests some connection between the party's popularity and fundraising. In contrast to Labour, this relationship is statistically significant in a regression analysis. Also, there is a larger, if still statistically insignificant relationship, between popularity and company donations. In contrast to general donors, it seems that companies reacted immediately and enthusiastically to Cameron's accession (c.f. Bale 2009: 228). The first two quarters of 2006 matched the two quarters preceding the election of 2010, in which, until very late on, most had expected a clear Conservative victory.

[Figure 2 about here]

[Figure 3 about here]

[Table 1 about here]

[Figure 4 about here]

[Figure 5 about here]

[Table 2 about here]

Figure 4 does not suggest that popularity affects the Labour party's ability to raise funds. Interestingly, Labour's most successful quarter by far was before it lost the general election of the 2010. Indeed, in this quarter Labour matched the Conservatives, as both raced towards the statutory spending limit. The increase in donations was very much out of proportion to the party's comeback in the polls. The pattern of company donations seems to reflect quite closely that of other private donations to Labour. There is little difference in the dynamics of general and company donations to the Labour party. Labour party donations do not seem to reflect the party's popularity, but overall donations increase as a general election approaches. The unimportance of polls is difficult to interpret for a governing party. 
It may demonstrate an ideological commitment to a party regardless of its future prospects of continuing in government or it may indicate a pragmatic concern to maintain good relations with a government regardless of its popularity. However, two pieces of evidence tentatively point towards the greater importance of the ideological motivation. Firstly, donations do increase as an election approaches. Such donations are wasted if the government loses power. Indeed, it is possible that a clear financial association with their competitors may earn the enmity of an incoming government. Of course, such a pattern also reflects the fact that parties fundraise more aggressively as elections approach. Nonetheless, pragmatic businesses should be able to resist their approaches. Secondly, Labour's most successful quarter for company donations was just before an unpopular government was ejected from power in 2010. Again, the most obvious interpretation is that these companies had an ideological preference for Labour.

By contrast, the two types of donors seem to behave differently in contributing to the Conservative party. Companies accounted for an average of 4.84 per cent of the quarterly private donations to the Labour Party, but 29 per cent of the quarterly private donations to the Conservatives. In spite of companies' much larger share of Conservative income, the correlation between company and other donations is much higher for the Labour party (0.8) than for the Conservatives (0.68). Overall Conservative donations are quite strongly associated with the electoral timetable, but not the party's popularity. By contrast, company donations do not seem to be affected by the closeness of an election. However, the figures suggest an intriguingly different reaction to the turning point provided by David Cameron's election to the leadership of the party, with companies reacting immediately and very noticeably, while other 
donors seemed to wait and, even then, contribute more cautiously. Thus, it is more likely that Tory-supporting companies are more pragmatically motivated than other Tory supporting donors, or any Labour supporters. Nonetheless, it is clear that companies donating to the Tories are not engaged in straightforward profit-seeking behaviour. Obviously, company donations to the opposition Tories dwarfed those to the governing Labour party. The most plausible interpretation is an interaction of ideological and pragmatic motivations. Companies are not minded to contribute to the Tories simply to express a preference for a pro-business political agenda. Instead, their willingness to spend money to support this ideological commitment depends on the electability of the Conservative party, as evidenced by the early company commitment to David Cameron.

\section{Big Business}

As already argued, there are many good reasons to suspect that very big businesses should behave differently to other companies. Moreover, the study of large businesses provides methodological opportunities not available when researching the wider business sector. In particular, the greater amount of available information and smaller number of businesses makes it easier to analyse firms at the individual level. It is also practical to study non-contributors as well as contributors, thereby avoiding the sample selection bias that affects so much of social science.

I drew down a sample of the 1005 largest UK-registered enterprises in the FAME database as of July 2009. This includes public and private companies as well as some partnerships. This dataset is available at http://www.dcu.ie/ mcmenami. 
[Table 3 about here]

Forty four separately listed firms made 174 separate financial contributions, summarised in Table 3. The table also reports payments to the Conservatives by individuals associated with the sample businesses. If substantial cross ownership is taken into account this figure reduces to thirty seven. These numbers are difficult to compare cross-nationally, due to differences in research design and, perhaps more critically, differences in disclosure regimes. Nonetheless, it is clear that Britain is very different to Australia and the U.S.A where it is quite normal for large firms to regularly contribute to political parties and Canada where donations were normal until they were banned. Britain's big firms also seem less involved than those in Germany, where they play quite a marginal role. Moreover, this data seems to confirm the common assumption that British parties have become less dependent on big business (c.f. Grant 1993: 142). However, the tiny contribution rate provides a striking contrast to Bond's study of Conservative donations between 1992 and 1996. He reports annual contribution rates of between nine and twenty-eight per cent for the 250 largest firms (Bond 2007: 65, 77).

Nine businesses made payments to Labour and the Tories; twenty to Labour alone; seven to the Tories alone; five to the Liberal Democrats alone and one (Tesco PLC) to Labour and the Liberal Democrats. No firm gave to both the Tories and the Liberal Democrats. These figures suggest that the Tories were no longer the only party of big business in this period. They had just over one third the numbers of exclusive supporters of Labour and only two more exclusive supporters than the Liberal Democrats. However, a handful of Tory firms made relatively large numbers of 
payments: KPMG LLP 22; FIL Investment Management 17 and Lewis Trust 15. The next highest number of contributions was 11 by Northumbrian Water to Labour. Multivariate analysis can help us begin to understand the motivation behind these payments, by examining the timing of payments in relation to the electoral timetable and popularity of the parties, while controlling for the basic characteristics of the firms themselves.

Table 4 presents a multinomial logit of big business payments to Labour and the Conservatives. There is a monthly observation for each firm until the 2010 general election. The dependent variable consists of three categories: non-contribution; contribution to Labour and contribution to the Conservatives. The base category is non-contribution, so there are two equations: one computing the probability of contributing to Labour compared to non-contribution and one comparing the probability of contributing to the Conservatives to non-contribution. The voting intention data comes from the ICM poll nearest to the middle of a given month. The poll variable is the percentage reporting an intention to vote for Labour minus the percentage reporting an intention to vote for the Conservatives and ranges from a twenty point Conservative Lead to a twenty-three point Labour lead. Pragmatic donors should give to the more popular party. Time to Election assumes that a general election is due every five years and divides the number of days until the next election by one hundred. Pragmatic donors should give to the government (i.e. Labour) when an election is distant and start to contribute to the opposition (i.e. the Conservatives) as the election approaches. Turnover and sectoral data came from the FAME database. However, some turnover figures had to be inter- or extrapolated and a very small number of companies were assigned sectoral codes by the author. The 
turnover figures have been logged to reduce the impact of outliers. Larger firms, with their greater financial resources, should be more likely to contribute. Sectors were coded according to the nine basic categories to the UK SIC 2003 classification, with sector one (fuel extraction, energy production and distribution, water supply) acting as the base category. The type of business in which a firm is engaged should affect its contribution strategy, although it is difficult to find a straightforward theory to map different sectors on to the two parties.

[Table 4 about here]

The results suggest that larger firms may be more likely to contribute to the Labour party but not to the Conservatives. Manufacturing firms, outside of metal, engineering and vehicles, are more likely to contribute to Labour, while those in finance and business services are less likely. Thus, the Labour equation fits the longestablished reputation of the party as being more sympathetic to manufacturing than the traditionally Conservative financial interests of the City of London. Firms in the mineral extraction and chemicals, finance and business services and research and other services sectors are less likely to contribute to the Conservatives. This equation does not support the supposed strong link between finance and the Conservative Party. The political variables can be used to draw inferences about the motivations of contributing businesses. The Poll variable is almost one and a half times more negatively associated with contributions to the Conservatives than to Labour. In other words, the more popular is Labour the less likely are firms to contribute to the Conservatives. The negative coefficient for the number of days to the election is also three times bigger for Conservative contributions than it is for Labour contributions. 
So, as an election draws nearer, firms are more likely to contribute to the opposition Conservatives. The measurement of the Poll variable assumes that firms react very quickly to opinion polls. Lagged values, which assume a slower reaction, produce broadly the same results. The largest lagged value is for two months previous to the month of the contribution. The lagged values affect the Conservative coefficient, but not that of Labour. The Conservative poll coefficient for two months previous to the payment is thirty per cent larger than the relatively immediate value reported above. Such increases in the poll value tend to somewhat attenuate the effect of the number of days to the election. Later lags continue to be statistically significant, but decline in power. The variance explained by the models is low. The equations do not provide a comprehensive explanation for business financing of parties, but they do illuminate the specific effect of political circumstances.

Multinomial logits are difficult to interpret directly. Therefore, I present some simulations to explore the substantive significance of the results. These use the method of recycled predictions from the model above setting one variable at the same level across all observations and keeping all other variables at sample values. Figure 6 presents predictions for different values of the poll of voting intentions. If the Conservatives hold a fifteen-point lead the model predicts a clear bias in business contributions towards the Conservatives. However, if Labour leads by the same amount, the model predicts that business will treat the two parties virtually equally. If there is no difference in the polls, a slightly higher probability of contribution to the Conservatives is predicted. Figure 7 simulates different times in the electoral calendar. If the election is imminent, the probability of contribution to the Conservatives is almost twice that of Labour. However, if the election is distant, 
contribution to the Labour government is more likely than to the Conservative opposition.

[Figure 6 about here]

[Figure 7 about here]

These simulations suggest an interaction of pragmatic and ideological motivations. Political donors amongst big British business tend to prefer the Conservatives. Under no circumstance, does business decisively prefer the Labour party. However, business only expresses its preference for the Conservatives under certain circumstances, namely an impending election or a Conservative lead in the opinion polls. Ideologically, the Conservatives better represent a pro-business vision of Britain, but pragmatically, businesses are mindful of the power of a Labour government. Interestingly, a very similar interaction can be observed in Australia (McMenamin 2008). American businesses also combine a preference for the right with pragmatic donations to both parties, although which comparisons are more difficult for regulatory and constitutional reasons (McMenamin 2010). The contribution rate of the largest businesses is very low in comparison to Australian, American and Canadian experience.

\section{Business leaders}

It is possible that firms coordinate donations with senior figures associated with the business. In this section, I test for that very possibility. The data comes from all payments over $£ 2000$ (the lowest figure in the company data) to Conservative Campaign Headquarters (CCHQ) and its predecessor Conservative Central Office from individuals. CCHQ received $32.25 \%$ of individual donations to the Tories and payments over $£ 2000$ to CCHQ consist of $29.74 \%$ of the total. The name of every 
contributor was researched to investigate whether they held a substantial number of shares or a senior position in any of the sample businesses at the time they made the payment. Predictably, most were businesspeople of some sort; many possessed titles or honours and some had held elective or appointed offices in the Conservative party. The information on most such contributors came from a fairly narrow range of wellknown sources such as the Houses of Parliament themselves, the Sunday Times Rich List, Zoom Business Info, and Debrett's. A handful of the contributors were associated with more than one of the sample businesses and were assigned to the firm with which they were most prominently connected. For example, Simon Robertson was a Director of HSBC, but chairman of Rolls Royce. So, he is primarily associated with Rolls Royce.

In no case did the Conservatives receive a contribution from a firm and from an individual prominently associated with that firm. More big British businesses are associated with the Tories through the donations of their large individual shareholders and senior staff than through direct payments from the business itself. However, these individuals made slightly fewer payments than did their businesses.

[Table 5 about here]

Table 5 presents two logit analyses of contributions to the Conservatives. The dependent variable is coded one for contributions to the Conservatives and zero for non-contribution or contributions to the other parties. Unsurprisingly, but reassuringly, the direct figures are very similar to those for the Conservative outcome in the multinomial logit presented in the previous section. The equation for contributions to the Conservatives by individuals associated with sample firms is very 
different. The coefficient for poll is only four per cent the size of the equivalent in the direct sample. The coefficient for days to election about seventy-two per cent of the size of its equivalent and reaches a very weak level of significance for such a large sample. Thus, while there is evidence for pragmatism in direct donations by big businesses to the Conservatives, there is little or no evidence of pragmatism in donations by individuals associated with big businesses. Since these individuals contribute to the opposition without regard to its popularity and pay no, or very little, heed to the electoral timetable it seems likely their motivation is ideological. This is consistent with the American literature, which tends to show that individual donations are much more ideological than corporate donations (Burris 2001). Thus, it seems that individual donations are just that. They are not indirect donations by big businesses. Although both are controversial, pragmatic donations are considered much more illegitimate than ideological donations. Therefore, if businesses were to donate through individuals, in order to reduce visibility, we would expect that such donations would be more, not less pragmatic, than direct corporate donations.

\section{Conclusions and discussion}

The highly transparent and permissive nature of the current British system of political finance regulation provides an excellent opportunity for studying business financing of political parties. The funding of British politics is heavily concentrated on the parties as organisations, rather than on candidates or officeholders. Company funding is important to the Conservative Party but not to the Labour Party. Indeed, without company funding the Conservatives would have had a considerably smaller income than the governing Labour Party over the last decade. However, these aggregate figures should not lead us to conclude that company funding of British politics as a 
purely ideological commitment to the Conservative Party. Company donors to the Conservatives behave quite differently to other donors in that their donations seem to be influenced by the party's electability. This effect is particularly obvious in the donations of the largest British businesses, which split their donations evenly between the two parties when the Labour party controls government and holds a commanding lead in opinion polls.

The importance of business funding to political competition is common to other liberal market economies, notably Australia and the United States, and under its previous regulatory regime, Canada. In liberal market economies, the highly competitive, short-term focus of firms should generate substantial demand for private goods that could help firms develop an advantage over their rivals. By contrast, in Germany's co-ordinated market economy, business plays a much more marginal role in political finance, as businesses define and pursue their interests collectively through business associations. The interaction of ideology and pragmatism is highly reminiscent of Australia and, to a lesser extent, the United States. The preference for less state intervention, and the awareness of the state's power to disrupt the business environment, is likely to engender a widespread awareness of the importance of public policy goods to the overall business sector. Again like Australia and the United States, British business's political donations reflect a clear division between the free-market right and a left concerned with social justice and social protection.

However, British behaviour also differs strikingly from other liberal countries. Firstly, the bias towards the Conservatives is much greater than the bias towards the right in Australia and the United States. Businesses make important contributions to 
the finances of the Democrats and the Australian Labor Party, but New Labour has failed to attract serious financial support from businesses. This is particularly striking given the Labour's long period of governing from the centre of the ideological spectrum. Secondly, while overall business funding remains important, all but a handful of the very largest businesses seem to have ceased funding the Conservatives since Labour took power. This is rather tricky to interpret. Contributing to a preferred party when in government, and abstaining when another party takes power, is a common strategy in other countries (McMenamin 2012). If this is correct, more very large businesses should start to contribute now that the Tories have returned to power. Alternatively, perhaps the ideological gap between the two parties has narrowed to the point where there is little ideological motivation for contributing. If this is accurate, widespread donations should not re-emerge unless and until the parties begin to polarise again. This interpretation sits uneasily with the continuing flow of business money to the Conservatives from outside the top one thousand. Nonetheless, in Britain, as elsewhere, it is usually assumed that smaller businesses have a stronger commitment to right-wing politics. Finally, there might be a regulatory explanation. Publicity and reputation are much more substantial costs for the largest businesses and payments by individual companies are now very easy to research. Moreover, a number of controversies in the Labour era may have raised awareness of the costs of any political activity by big business (Hencke 2007; Wintour 2008; Booth 2009; Woolf, Milland and Watts, 2010). Under this scenario, the withdrawal of big business from political finance is likely to be relatively permanent. The last difference between Britain and other liberal countries is the nature of the exchange between pragmatic contributors and parties. In contemporary Australia (McMenamin 2008: 378-9) and the United States (Clawson, Neustadtl and 
Weller 1998: 63-138), and in the past in Canada (McMenamin 2012), businesses have been able to purchase access to politicians. In Britain there have been some cases of the sale of access by individual politicians (Ivens 2009; Watt 2009; Groves 2010), but the parties and the government do not seem to have been involved. A discrete exchange like the sale of access is unlikely to explain most of the pragmatically-timed Conservative donations. Instead, perhaps such payments sought a reciprocal exchange of money now for a possible policy benefit in the future (McMenamin 2012). Another possibility is that British pragmatism is aimed at the avoidance of costs rather than the pursuit of benefits. Perhaps large businesses have desisted from donating to the Conservative party in order to avoid some form of punishment from the Labour government. The recent change of government provides an opportunity for students of British and comparative politics to probe these questions using both quantitative and qualitative methods. 


\section{Appendix: Loans and British Political Finance}

Figure A1 demonstrates that the Conservatives have been more dependent on loans than Labour. This is hardly surprising given that they have been in opposition for all of the relevant period and have been an unpopular opposition for most of that time. While the commercial basis for loans from banks is obvious, the motivation for the loans by other companies and by individuals is more mysterious. The sources of the loans are very different for the two parties. Labour received several seven-figure loans from individuals. These are the loans that were the subject of the "loans-forpeerages" controversy, which led to the police questioning prime minister Tony Blair as a witness. Labour borrowed virtually all remaining money from retail banks. By contrast, the Conservatives' largest borrowings were from financial institutions, with substantial loans from both retail banks and more specialised private banks and other financial services firms. Officially, the Tories also borrowed almost seven million from other businesses. However, most of this seems to have been a (legal) way of trying to preserve the anonymity of large donations by wealthy individuals (Doward 2008). Even if these loans are reclassified, the Conservatives were much more dependent on loans from financial institutions than Labour. The Conservatives have already repaid the vast majority of the money they borrowed - seventy seven per cent. The situation is different for Labour, which has paid back only forty-three per cent of the money borrowed. The difference between amounts borrowed and repaid is relatively small for business loans. The low rate of repayment of individual loans to Labour is the chief reason for this difference between the two parties. Of course, these statistics do not take into account the terms, interest rates or financial situations of the parties. Indeed, a handful of large loans may have been paid back precisely because it was suspected that they were disguised donations. Regression analyses 
(not shown) suggest that there was no relationship between loans and the electoral timetable and the standing of the parties in the polls. In other words, these loans are unlikely to be disguised pragmatic donations. Instead, they are likely to be normal commercial loans or a variety of ideological donation to the parties.

Within the sample of very large businesses, only banks have made loans to the parties. Therefore, it seems very unlikely that the loans were attempts to disguise donations. HSBC and Lloyds made small loans to both parties. During the sample period the Co-operative Bank made 10 loans to the Labour party, totalling over 5.5 million. ${ }^{1}$ The Conservative party received no large loans from sample firms. Its biggest debt of 18.5 million was incurred to Irish bank, AIB in 2006.

The principal parties have also received major loans from individuals associated with very large businesses. There is only one such lender for the Conservatives: Lord Laidlaw of Rothiernay lent three and a half million, most of which was converted to a donation. The size of the loans, and their clear bias towards the government, suggest that there may have been a pragmatic motivation behind the loans. Nonetheless, these loans seem more likely to have been a personal pursuit of honours rather than a way of pursuing a business interest, while evading disclosure regulations.

[Figure A1 about here]

\footnotetext{
${ }^{1}$ The Co-operative Bank was not included in the sample, but its sister company Co-operative Insurance was.
} 
TABLE 1

REGRESSION ANALYSES OF DONATIONS (£s) TO THE CONSERVATIVES

\begin{tabular}{|c|c|c|c|c|}
\hline & \multicolumn{2}{|c|}{ Private donations } & \multicolumn{2}{|c|}{ Company donations } \\
\hline & $b$ coefficient & robust S.E. & $b$ coefficient & robust S.E. \\
\hline Poll (percent) & 80.27 & 65.53 & 35.47 & 18.94 \\
\hline $\begin{array}{l}\text { Days to } \\
\text { election }\end{array}$ & -3.32 & $1.29 *$ & -.28 & .37 \\
\hline Constant & 7512.16 & $1198.93 * *$ & 1521.57 & $374.87 * *$ \\
\hline $\mathrm{F}$ & \multicolumn{2}{|c|}{$12.64 * *$} & \multicolumn{2}{|c|}{$7.14^{* *}$} \\
\hline $\mathrm{R}^{2}$ & \multicolumn{2}{|c|}{0.35} & \multicolumn{2}{|c|}{0.21} \\
\hline Observations & \multicolumn{2}{|c|}{38} & \multicolumn{2}{|c|}{38} \\
\hline
\end{tabular}

Note: $*=$ significant at $5 \% ; * *=$ significant at $1 \%$. 
TABLE 2

REGRESSION ANALYSES OF DONATIONS (£s) TO LABOUR

\begin{tabular}{lcccc}
\hline & \multicolumn{2}{c}{ Private donations } & \multicolumn{2}{c}{ Company donations } \\
\cline { 2 - 6 } Poll (percent) & $b$ coefficient & robust S.E. & b coefficient & robust S.E. \\
$\begin{array}{l}\text { Days to } \\
\text { election }\end{array}$ & 12.57 & 38.13 & 2.61 & 3.32 \\
Constant & $-2.03^{*}$ & .95 & -.17 & .09 \\
F & 6129.47 & 1098.52 & 369.11 & 98.34 \\
$\mathrm{R}^{2}$ & & 3.11 & & 2.13 \\
Observations & 0.23 & & 0.17 \\
\hline
\end{tabular}

Note: $*=$ significant at $5 \%$. 
TABLE 3

DONATIONS BY VERY LARGE FIRMS

\begin{tabular}{lccc}
\hline & Payments & Businesses & Individuals \\
\hline Labour & 72 & 29 & NA \\
Liberal Democrats & 11 & 6 & NA \\
$\begin{array}{l}\text { Conservatives } \\
\text { Conservatives } \\
\text { (associated individuals) }\end{array}$ & 91 & 17 & NA \\
\hline
\end{tabular}


TABLE 4

MULTINOMIAL LOGIT OF CONTRIBUTIONS TO LABOUR AND THE CONSERVATIVES

\begin{tabular}{|c|c|c|}
\hline & $b$ coefficient & $\begin{array}{c}\text { robust S.E. } \\
\text { clustered by business }\end{array}$ \\
\hline \multicolumn{3}{|l|}{ Labour } \\
\hline Poll (percent) & -.04 & $.01 * *$ \\
\hline Turnover (logged) & .44 & .26 \\
\hline Time to Election & -.04 & .03 \\
\hline Mineral extraction, chemicals & .10 & 1.25 \\
\hline Metal goods, etc. & 1.58 & .96 \\
\hline Other manufacturing & 1.93 & $.98^{*}$ \\
\hline Construction & 1.21 & .95 \\
\hline Wholesale, retail, etc. & 1.05 & .98 \\
\hline Transport \& communication & .13 & .90 \\
\hline Finance, business services & -32.64 & $.83 * * *$ \\
\hline Research, other services & 1.32 & 1.27 \\
\hline Constant & -14.40 & $4.06 * * *$ \\
\hline \multicolumn{3}{|l|}{ Conservatives } \\
\hline Poll (percent) & -.06 & $.02 * * *$ \\
\hline Turnover (logged) & -.10 & .13 \\
\hline Time to Election & -.09 & $.04 * *$ \\
\hline Mineral extraction, chemicals & -33.00 & $.67 * * *$ \\
\hline Metal goods, etc. & -.18 & 1.19 \\
\hline Other manufacturing & .86 & .84 \\
\hline Construction & .73 & 1.01 \\
\hline Wholesale, retail, etc. & .75 & 1.15 \\
\hline Transport \& communication & 1.28 & .98 \\
\hline Finance, business services & -34.12 & $.62 * * *$ \\
\hline Research, other services & -34.04 & $.68 * * *$ \\
\hline Constant & -5.79 & $1.95 * *$ \\
\hline Observations & \multicolumn{2}{|c|}{125625} \\
\hline Businesses & \multicolumn{2}{|c|}{1005} \\
\hline Log pseudolikelihood & \multicolumn{2}{|c|}{-1257.52} \\
\hline Wald chi ${ }^{2}$ & \multicolumn{2}{|c|}{$26522.05^{* * *}$} \\
\hline Pseudo R ${ }^{2}$ & \multicolumn{2}{|c|}{0.064} \\
\hline
\end{tabular}

Notes: The base category for the dependent variable is non-contribution. The base category for the sectoral dummies is extraction of fuels, fuel processing and production. There were two cases in which a firm contributed to both Labour and Conservatives in one month. In both cases, the larger donation was to the Conservatives, so these have been coded as Conservative contributions in the analysis above. Note: * $=$ significant at $5 \% ; * *=$ significant at $1 \% ; * * *$-significant at $0.1 \%$ 
TABLE 5

\begin{tabular}{|c|c|c|c|c|}
\hline & \multicolumn{2}{|c|}{ Individuals } & \multicolumn{2}{|c|}{ Businesses } \\
\hline & $b$ coefficient & $\begin{array}{c}\text { robust } S . E . \\
\text { clustered by } \\
\text { business }\end{array}$ & $b$ coefficient & $\begin{array}{l}\text { robust S.E. } \\
\text { clustered by } \\
\text { business }\end{array}$ \\
\hline Poll (percent) & .00 & .02 & -.06 & $.02 * * *$ \\
\hline Turnover (logged) & .37 & .28 & -.10 & .13 \\
\hline Time to Election & -.07 & .04 & -.09 & $.04 * *$ \\
\hline Mineral extraction, chemicals & .52 & .89 & dropped & dropped \\
\hline Metal goods, etc. & -1.13 & 1.11 & -.18 & 1.19 \\
\hline Other manufacturing & .27 & 1.11 & .85 & .84 \\
\hline Construction & .56 & .65 & .73 & 1.01 \\
\hline Wholesale, retail, etc. & .16 & .70 & .75 & 1.15 \\
\hline Transport \& communication & .39 & .74 & 1.28 & .98 \\
\hline Finance, business services & .40 & 1.08 & dropped & dropped \\
\hline Research, other services & dropped & dropped & dropped & dropped \\
\hline Constant & -12.22 & $4.19 * *$ & -5.79 & $1.95^{* *}$ \\
\hline Observations & \multicolumn{2}{|c|}{120875} & \multicolumn{2}{|c|}{106750} \\
\hline Businesses & \multicolumn{2}{|c|}{967} & \multicolumn{2}{|c|}{854} \\
\hline Log pseudolikelihood & \multicolumn{2}{|c|}{-662.911} & \multicolumn{2}{|c|}{-696.31} \\
\hline Wald chi ${ }^{2}$ & \multicolumn{2}{|c|}{$24.70 * *$} & \multicolumn{2}{|c|}{$107.67 * * *$} \\
\hline Pseudo R2 & \multicolumn{2}{|c|}{0.026} & \multicolumn{2}{|c|}{0.052} \\
\hline
\end{tabular}

Notes: The base category for the dependent variable is non-contribution or contribution to one of the other parties. The base category for the sectoral dummies is extraction of fuels, fuel processing and production. Sectors in which no firm contributed have been dropped. Note: $*=$ significant at $5 \%$; **=significant at $1 \%$; $* * *$-significant at $0.1 \%$. Some sectors were dropped due to lack of variation in the dependent variable. 
FIGURE 1

SOURCES OF DONATIONS TO THE PARTIES

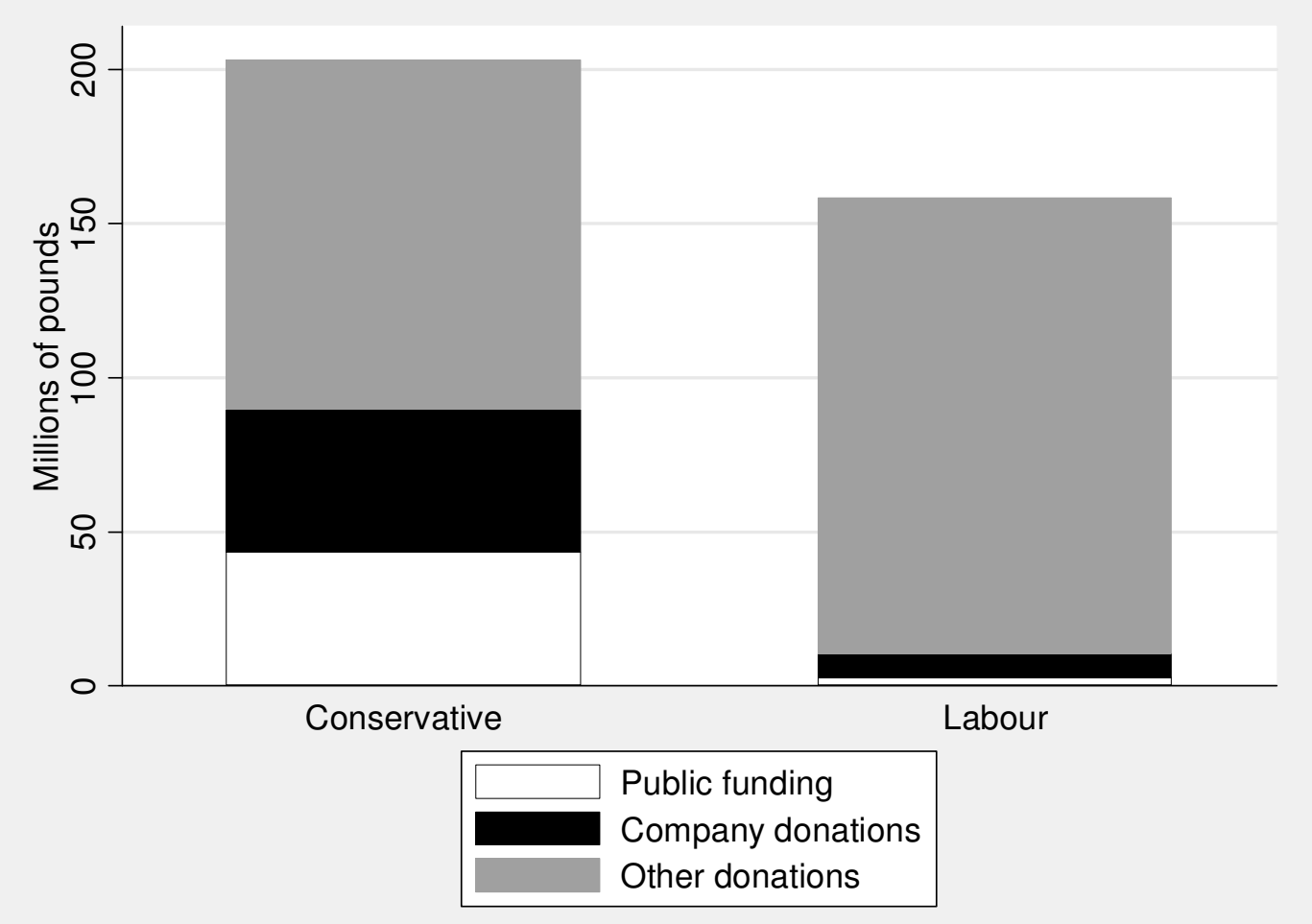

Source: Author's analysis of data collected by the UK Electoral Commission 
FIGURE 2

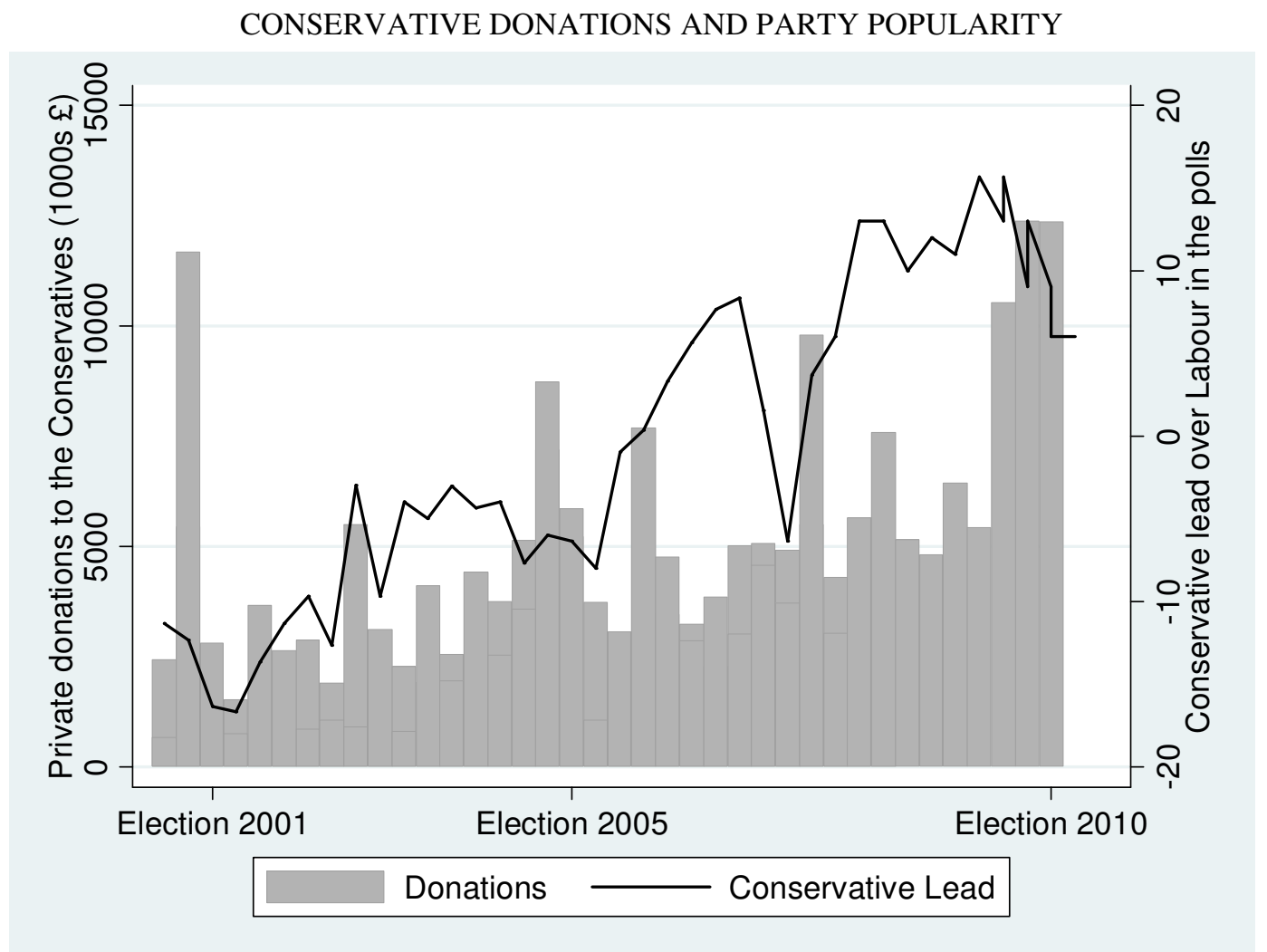

Source: Author's analysis of quarterly data from the UK Electoral Commission Political Finance Register. Public funds, received by the opposition Conservatives, but not the governing Labour party, are listed as donations by the UK Electoral Commission, but have not been included here. 
FIGURE 3

COMPANY DONATIONS TO THE CONSERVATIVES AND PARTY POPULARITY

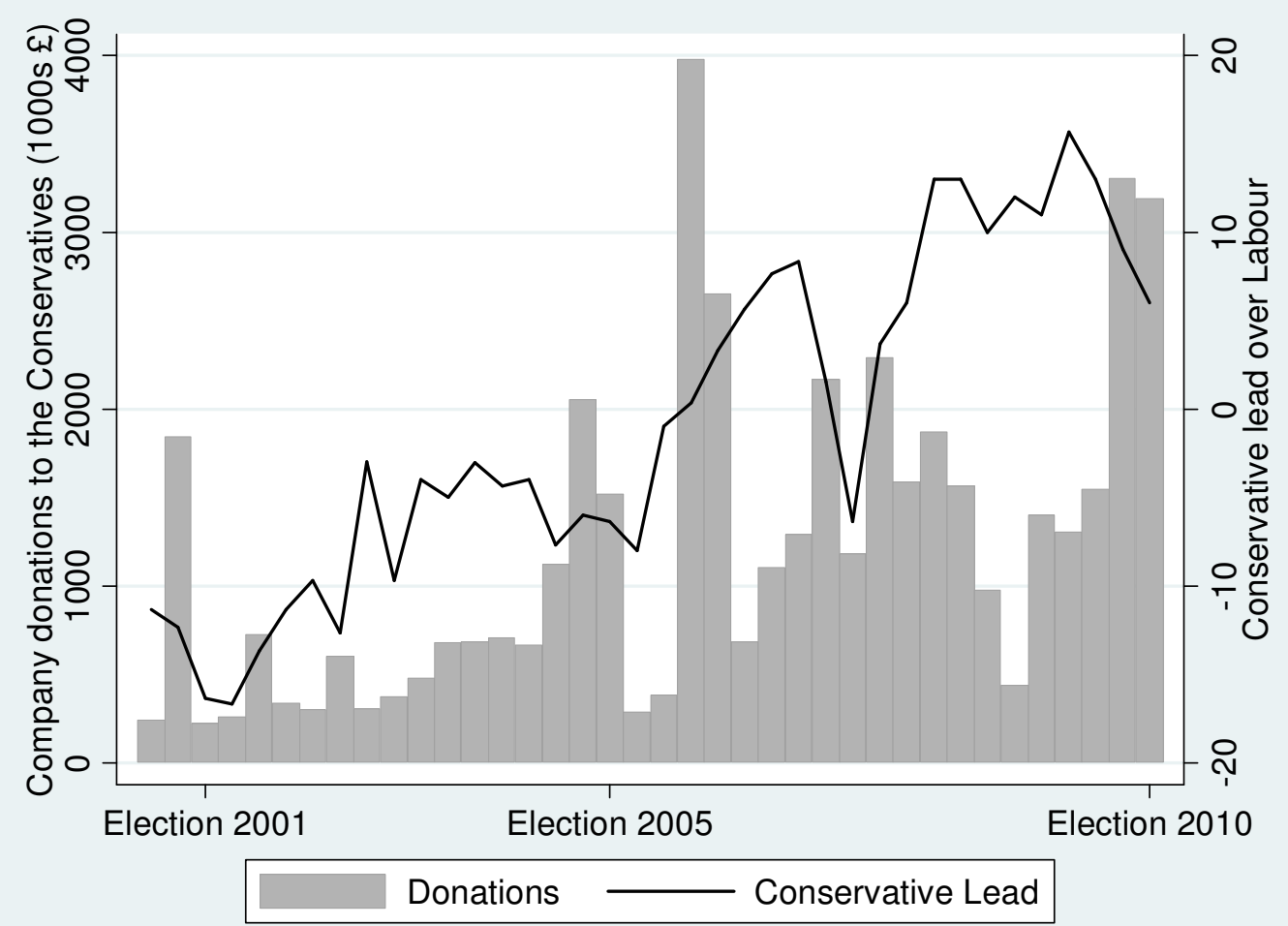

Source: Author's analysis of quarterly data from the UK Electoral Commission Political Finance Register 
FIGURE 4

LABOUR DONATIONS AND PARTY POPULARITY

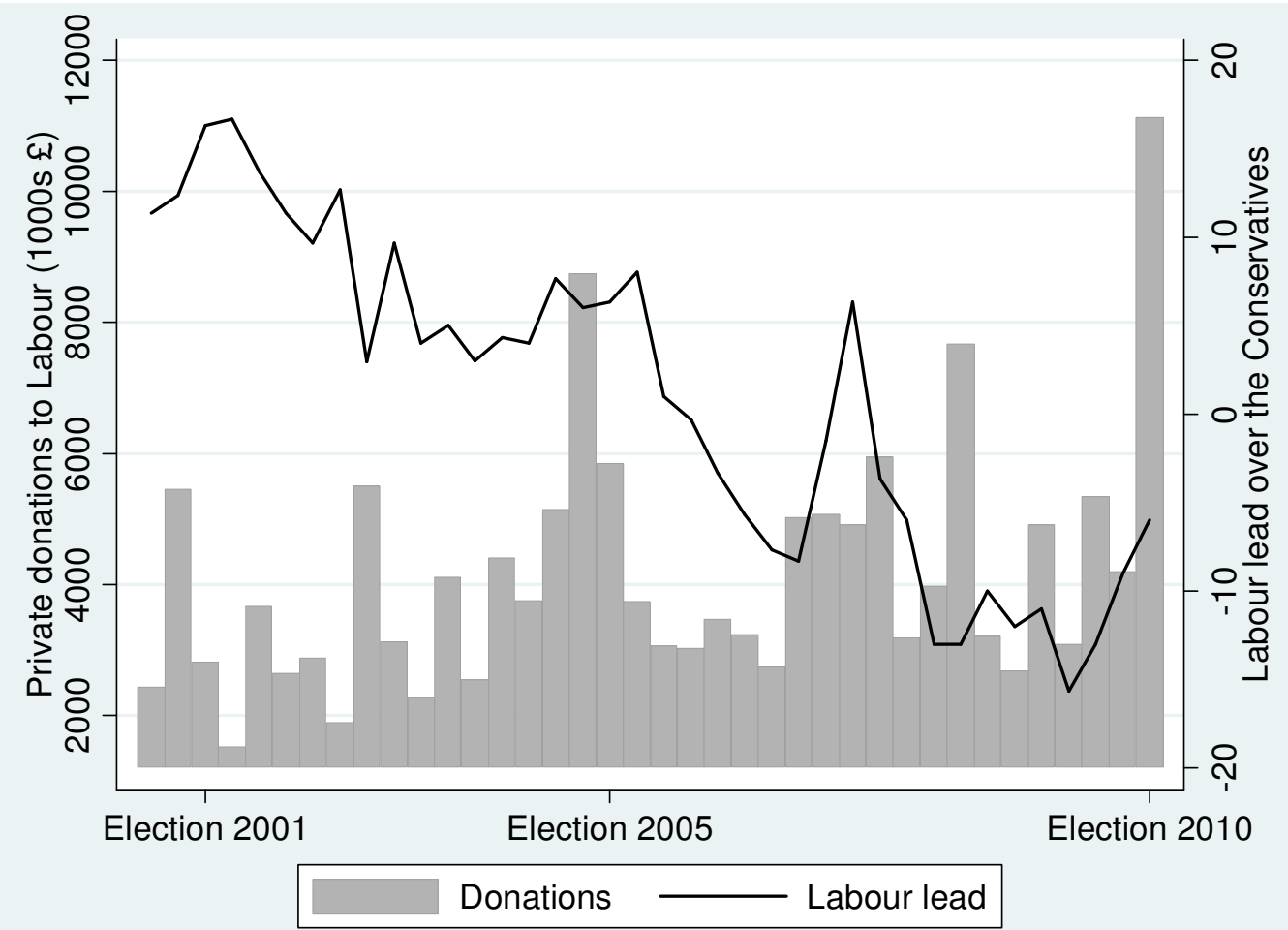

Source: Author's analysis of quarterly data from the UK Electoral Commission Political Finance Register. 
FIGURE 5

COMPANY DONATIONS TO LABOUR AND PARTY POPULARITY

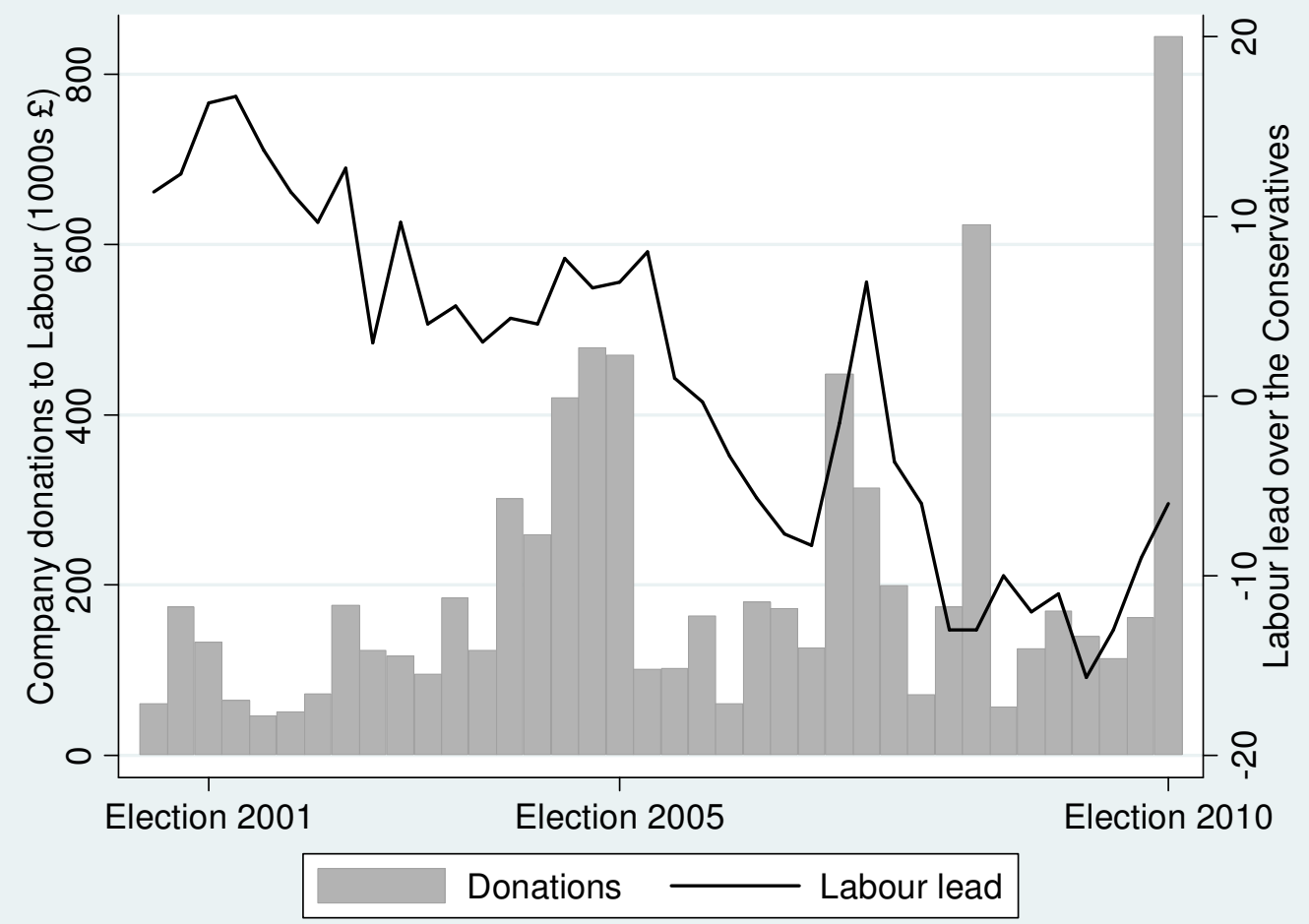

Source: Author's analysis of quarterly data from the UK Electoral Commission Political Finance Register 
FIGURE 6

SIMULATIONS ACCORDING TO THE POPULARITY OF THE PARTIES

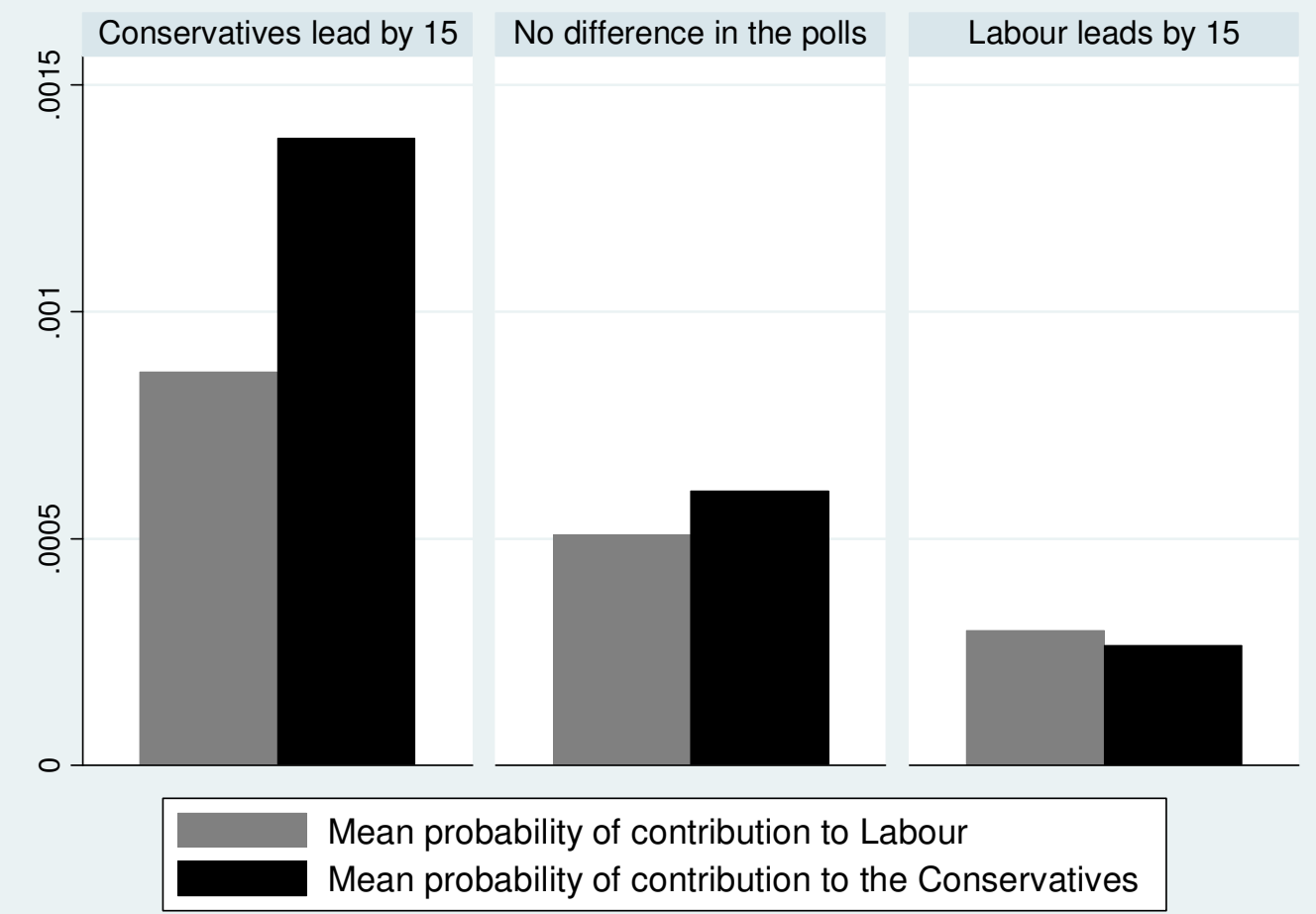

Note: Derived from equations in Table 4 
FIGURE 7

SIMULATIONS ACCORDING TO THE ELECTORAL TIMETABLE

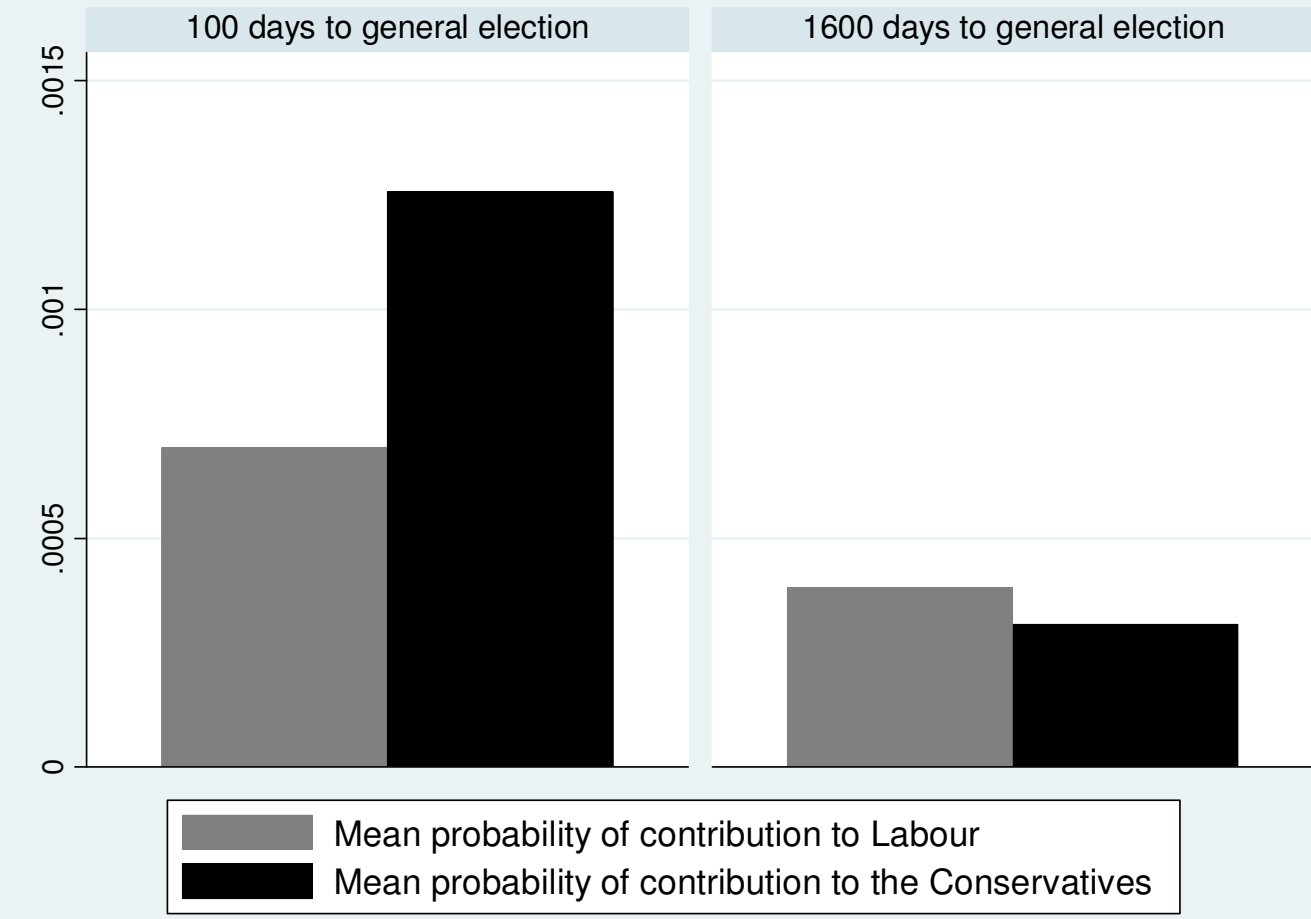

Note: Derived from equations in Table 4 
FIGURE A1

SOURCES OF LOANS TO THE PARTIES: 2001-MAY 2010

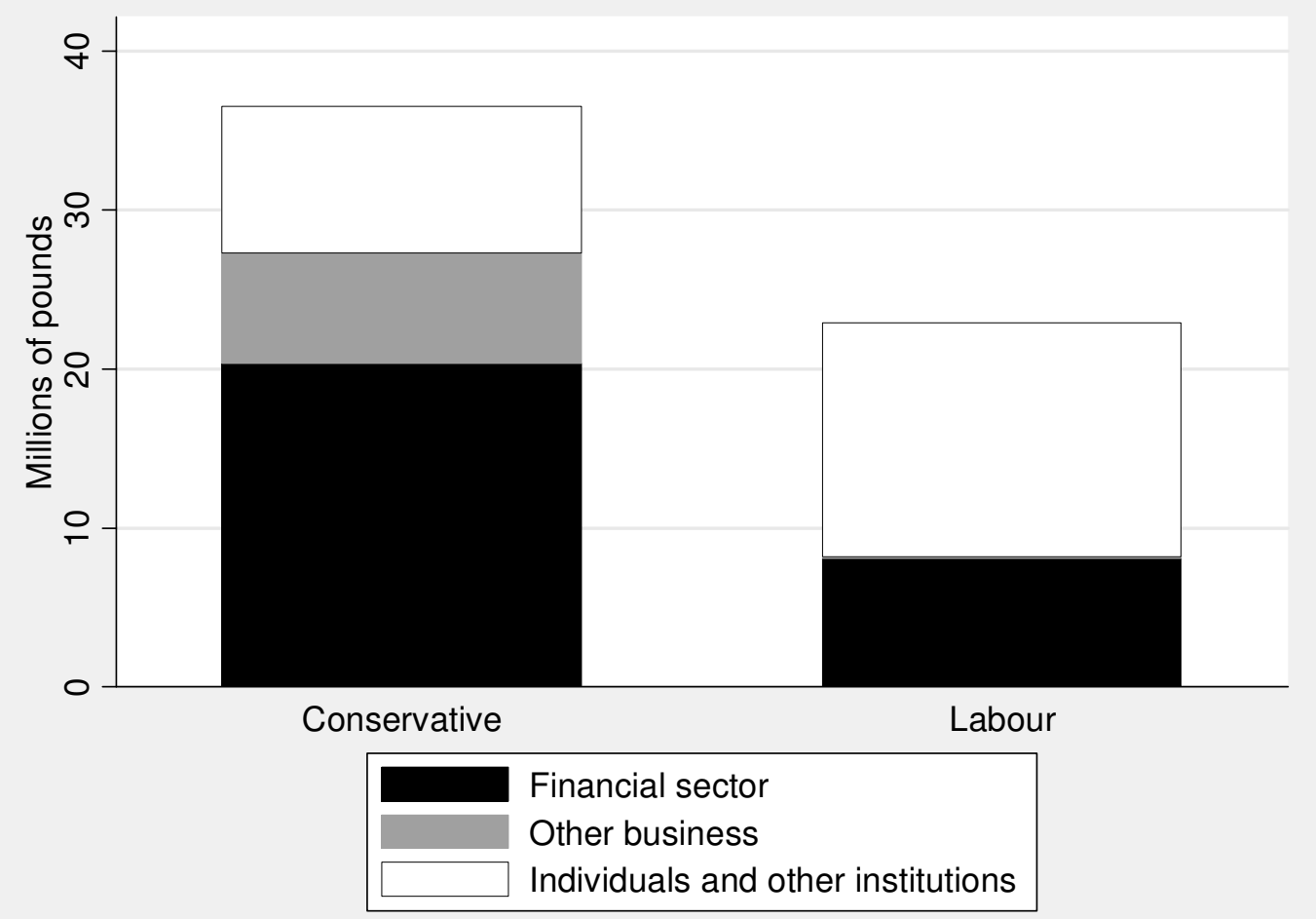

Source: UK Electoral Commission 


\section{References}

Bale, Tim. (2009) 'Cometh the Hour, Cometh the Dave': How Far is the Conservative Party's Revival All Down to David Cameron?', Political Quarterly, 80:2, 222-232.

Bond, Matthew. (2004) 'Social Influences on Corporate Donations in Britain', British Journal of Sociology, 55:1, 55-77.

Bond, Matthew. (2007) 'Elite Social Relations and Corporate Political Donations in Britain', Political Studies, 55:1, 59-85.

Booth, Robert. (2009) 'Tory tax allies 'subsidised' by the taxpayer', The Guardian, Home, December 21, p. 1

Burris, Val. (2001) 'The Two Faces of Capital: Corporations and Individual Capitalists as Political Actors,' American Sociological Review, 66:3, 361-81.

Clawson, Dan, Neustadtl, Alan and Weller, Mark. (1998) Dollars and Votes. Philadelphia, PA: Temple University Press.

Coen, David (1997) 'The evolution of the large firm as a political actor in the European Union', Journal of European Public Policy, 4:1, 91-108.

Coen, David and Grant, Wyn (2006) 'Managing Business and Government Relations', in David Coen and Wyn Grant, (eds.), Business and Government: Methods and Practice. Opladen: Barbara Budrich, 13-32.

Doward, Jamie \& Syal, Rajeev. (2008) "Hidden loan that boosted Tories", The Observer. 26 October 2008.

Ewing, Keith D. (2007) The Cost of Democracy: Party Funding in Modern British Politics. Oxford: Hart.

Fisher, Justin. (1994) 'Why Do Companies Make Donations to Political Parties?', Political Studies, 42:4, 690-699.

Fisher, Justin. (1999), 'Party expenditure and electoral prospects: a national level analysis of Britain', Electoral Studies, 18:4, 519-32.

Fisher, Justin. (2000) 'Economic performance or electoral necessity? Evaluating the system of voluntary income to political parties', British Journal of Politics and International Relations, 2:2, 179-204.

Fisher, Justin. (2009) 'Hayden Phillips and Jack Straw: The Continuation of British Exceptionalism in Party Finance?', Parliamentary Affairs, 62:2, 298-317.

Gordon, Stacy. (2005) Campaign Contributions and Legislative Voting (New York, NY: Routledge)

Gordon, Michael and Ceresa, Maria. (1995) 'ALP intimidates business for funds: Libs,' The Weekend Australian. July 8.

Grant, Wyn. (2000) Business and Politics in Britain, $2^{\text {nd }}$ ed. London: Macmillan, 1993. 
Groves, Jason. (2010) "Cash-for-access scandal MPs in line for peerages", The Daily Mail, News, 24 March.

Hall, Peter and Soskice, David (2001) 'An Introduction to Varieties of Capitalism' in Peter Hall and David Soskice (eds.), Varieties of Capitalism: The Institutional Foundations of Comparative Advantage. Oxford: Oxford University Press, 71-103.

Hencke, David. (2007) 'Cash for honours: From a 'ploy' by the SNP to a crisis that rocked Labour', The Guardian, Home, July 20, p. 4.

Ivens, Martin. (2009) 'Dirty deals bring an end to the peer show', The Sunday Times, Features, February 1, p. 17

Iversen, Torben 2005. Capitalism, Democracy, and Welfare. Cambridge: Cambridge University Press.

Lindblom, Charles. (1977) Politics and Markets: The World's Political-Economic Systems. New York: Basic Books.

McMenamin, Iain. (2008) 'Business, Politics and Money in Australia: Testing Economic, Political and Ideological Explanations', Australian Journal of Political Science, 43:3, 377393.

McMenamin, Iain. (2009) 'The Four Logics of Business, Money and Political Parties', in Conor McGrath (ed.), Interest Groups and Lobbying, Vol. 1. Lewiston: Edwin Mellen, 2009, 207-224.

McMenamin, Iain (2010) 'Time to Travel in Search of the Political Market'. Working Papers in International Studies Series, 2010-11. Dublin: Dublin City University

McMenamin, Iain (2012) 'If Money Talks, What Does it Say? Varieties of Capitalism and Business Financing of Parties', World Politics, 64:1.

Mitchell, Neil J. and Bretting, John G. (1993), 'Business and Political Finance in the UK', Comparative Political Studies 26:2, 229-245.

Olson, Mancur. (1971) The Logic of Collective Action: Public Goods and the Theory of Groups. Cambridge MA: Harvard University Press.

Scarrow, Susan E. (2006) 'Money, Politics, and the Balance of Power: Comparing Official Stories', Annual Meeting of the American Political Science Association, Philadelphia, PA.

Scarrow, Susan E. (2007) 'Political Finance in Comparative Perspective', Annual Review of Political Science, 10, 193-210.

Stratmann, Thomas. (2005) 'Some talk: Money in politics. A (partial) review of the literature.' Public Choice 124, 135-156.

Vogel, David. (1996) Kindred Strangers: The Uneasy Relationship between Politics and Business in America. Princeton, NJ: Princeton University Press.

Wintour, Patrick. (2008) 'Miliband calls for loyalty to Brown after Levy claims", The Guardian, Home, April 28, p. 4 
Watt, Nicholas. (2009) 'Erminegate: police called to examine corruption allegations in House of Lords', The Guardian, Home, January 26, p. 3

Wood, Stewart (2001) 'Business and Labor Market Policy in Britain and the Federal Republic of Germany' in Peter Hall and David Soskice (eds.), Varieties of Capitalism: The Institutional Foundations of Comparative Advantage. Oxford: Oxford University Press, 247-274

Woolf, Marie. (2010) 'He's bankrolled the Tories with diggerful of cash' The Sunday Times, News, May 30, p. 4. 